\title{
PROGRESS OF THE RESTITUTION OF THE BISON (BISON BONASUS L.) IN POLAND
}

\author{
by \\ Dr. JAN ŻABIŃSKI \\ Director of the Zoological Gardens, Warsaw
}

The history of the European bison gives us a most striking example how some species of animals disappear gradually while being deprived of their natural surroundings. In Western Europe, where the increase of population and development of rural settlements showed a quicker progress than in the East of the continent, the bisons were regarded as Royal game already since the VII-th or VIII-th century and attemps have been made to protect them more or less. Nevertheless the area of the distribution of the bison shrank rapidly and at the beginning of the XIX-th century was restricted only to the Białowieża Forest. It should be added, however, that over 50 years ago the occurence of the bisons was discovered also at another place namely on the North-Western slopes of the Caucasus. These Caucasian bisons were, however, completely exterminated recently and the species exists there no more since about 8 years.

That part of Poland in which the Białowieża Forest is situated belonged at the beginning of the XIX-th century to the territory of the Russian Empire. The Tzar of Russia issued in 1803 a Decree according to which a special imperial license had to be obtained in every particular case for shooting or capturing a bison at the Białowieża Forest. The decree established also a careful protection of the bisons.

As it may be seen from the table given below the number of bisons was increasing, however, only during the first half of the XIX-th century.

\begin{tabular}{|c|c|c|c|c|c|c|c|c|c|c|c|}
\hline 1810 & - & $35^{\circ}$ & jisons & 1850 & 一 & I 560 & bisons & 1890 & - & 403 & bisons \\
\hline 1820 & - & 528 & $"$ & I860 & - & I 575 & " & I900 & -- & 727 & " \\
\hline & & 772 & " & 1870 & - & 542 & " & I910 & about & 600 & \\
\hline 184 & - & 817 & $"$ & I 880 & - & 579 & $"$ & & & & \\
\hline
\end{tabular}

The world war put an end to the original Białowieża herd. There were at a certain time animated controversies as to the actual responsibility in connection with the extermination of the bisons in the Białowieza Forest. In some German press articles and various publications of a similar kind the local population 
was pointed at as the exterminator of the bisons. Similarly on the Polish and Russian side the press accused the German army, because a remarkably strong decrease of the number of the animals in question took place at the time when the Białowieża Forest was under German military administration.

The impartial judgement of a naturalist sees at once the lack of any good reason in such a controversy. There is scarcely any doubt that both parties are responsible to a certain extent but strictly speaking it is primarily the fatal coincidence of various circumstances that played the main part in this sad story. From 1915 to 1920, not less than four times, the fighting line passed across the Białowieza Forest. The Forest changed its occupants and administration: Russians, Germans, Lithuanians (during a fortnight), Poles Bolsheviks and finally Poles again. It is not surprising, therefore, that under such conditions the care and protection of the bison was far from being sufficient and that the scarcely protected animals were doomed to disappear.

If we try to illustrate the facts by means of figures, it appears that in I9I 5 the German army entering the Białowieża Forest found there only about 400 bisons. After the armistice in 1918 and the abolition of the Eastern GermanRussian front there still remained in the Białowieża Forest about 200 bisons. These were practically exterminated during the Polish-Bolshevik war of 19191920 and the beginning of I92I only a single bison cow was known to have survived in the Białowieża Forest; unfortunately she fell also a few days after this information had reached definitely the competent forest authorities.

The bisons were brought back to the Białowieża Forest in 1929. At that time the Polish Ministry of Agriculture in cooperation with the Zoological Garden of Warsaw has purchased in Sweden, through the intermediacy of Messrs Hagenbeck, three pure breed specimens and two hybrid cows (with an admixture of American bison blood). These animals were placed in the Białowieża Forest in a special enclosure surrounded by a $2,5 \mathrm{~m}$ high fence made of wooden boards $4 \mathrm{~cm}$ thick. In the enclosure all the necessary precautions were taken: even the feet of those who entered it were disinfected and special isolating areas were left between the four paddocks of the enclosure.

The following table shows the gradual increase of the renewed herd of bisons.

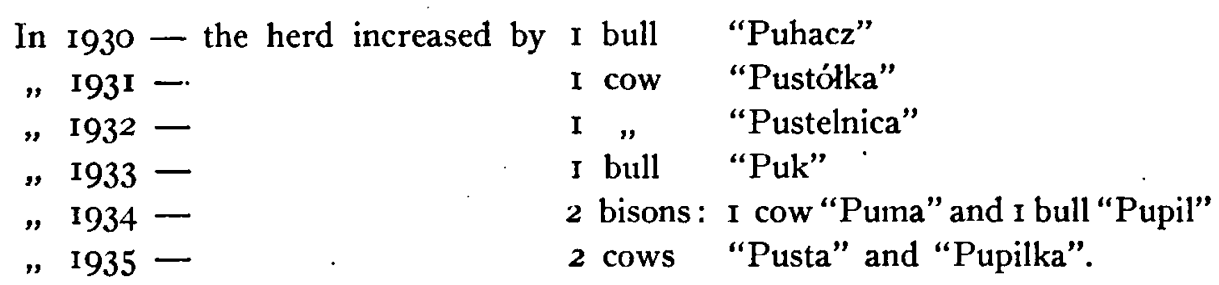

In 1935 moreover "Pustółka" and "Pustelnica" were exchanged in Sweden for "Bilma" and "Björnson". Björnson fell in the same year. The hybrid cows 
and their offsprings, six animals on the whole, were transferred to a new reserve Forestry, district of Opoczno, Province of Kielce (distance from the Białowieza Forest about $400 \mathrm{klm}$ West South-West).)

In 1936 - the herd increased by 2 bisons: I cow "Pustota" and

I bull "Purytanin".

"Pupil" was sent to Schorfheide (Germany) in exchange for a hybrid European-American bison cow.

In 1937 - the herd increased by 2 bisons: I bull "Pulchny" and

I cow "Polka".

Thus this year the renewed Białowieza herd counts I 3 heads, 8 cows and 5 bulls. The herd at Smardzewice consists of I pure bull and I 3 hybrids.

This year also we have begun in Poland with the establishment of a third bison reserve in the vicinity of Kraków. It is intended to transfer to that new reserve those animals which have an admixture of Caucasian blood and to try to breed there the Caucasian form of the bison, by way of gradual genetic elimination. 'This has been hitherto somewhat neglected by bison breeders.

To complete this short note it should be added that we have in Poland still another bison herd of I6 heads descending from specimens which were presented in 1864 by the Russian Tzar to the Prince of Pless. These are being kept in the forests belonging to the Prince of Pless, in the Province of Silesia. Thus on December 31st, 1937, there were in Poland 30 bisons of pure breed and I 7 hybrids (class $\mathrm{I}-\mathrm{V}$ according to the International Bison Register). 